\title{
Conditions for the Educational Process Implementation in the Digital Environment
}

\author{
Svetlana V. Gaisina 1[ORCID 0000-0002-0576-1752], \\ Vasily P. Panasyuk 1[ORCID 0000-0002-1643-7042], \\ Roza M. Sherayzina 2[ORCID 0000-0002-7358-0689], \\ Marina V. Alexandrova 2[ORCID 0000-0003-1745-4730], \\ Natalya V. Alexandrova $\left.{ }^{2 *[O R C I D} 0000-0001-9115-0378\right]$
}

\author{
${ }^{1}$ Saint Petersburg Academy of Postgraduate Pedagogical Education, Saint Petersburg, Russia \\ ${ }^{2}$ Yaroslav-the-Wise Novgorod State University, Veliky Novgorod, Russia \\ Natalya.Alexandrova@novsu.ru
}

\begin{abstract}
The process of digital transformation of education started to actively develop with the approval of the "Digital Economy of the Russian Federation" national program (order of the Government of the Russian Federation dated July 28, 2017 No. 1632-p), in which "personnel and education" is defined as one of the five basic directions of the Russian digital economy development for the period up to 2024. The digital transformation of all socioeconomic systems requires the education system to introduce new approaches to the implementing the learning process, as well as the developing and testing new competency models that ensure effective interaction between society, business, the labour market and education in the digital economy. This study focuses on identifying existing deficits and difficulties in the process of introducing digital technologies into the educational process in terms of the readiness of all groups of educational relations participants: teachers, students and their parents (for example, educational organizations in St. Petersburg, Russia). Their subjective assessment of the conditions for implementing educational process with the use of a digital educational environment and distance education technologies is considered as a significant assessment indicator. What is more, a difference in the selfassessments of the educational relations participants' readiness to work in a digital educational environment (using distance education technologies), presented in studies conducted before and during the COVID-19 pandemic, has been recorded. A comparative analysis of the results of surveys conducted at the regional and national levels did not reveal significant differences, which proves the validity of the assessment of the results obtained. Based on the results of the study, it is concluded, in general, that the digital environment for the educational process organization is formed against the background of the insufficient readiness of teachers, students and their parents, objectively justified by the conditions for its implementation.
\end{abstract}

Keywords: educational relations participants, digitization, learning personalization, distance learning, digital educational environment, digital technologies

\section{INTRODUCTION}

Changing working and living conditions in the information society and, as a result, the transition to the digital economy require the formation and development of skills and abilities that did not exist before, new ways of working in the professional sphere. Internet communication and the use of digital means are widely used in everyday life, but they cause difficulties for the teacher when implementing in the educational process. The digitalization of education is a process that causes a lot of controversy based on both opposing views and misunderstandings between the participants considering the emerging terminological apparatus for operating new methods and types of activities. There are different approaches to determining the competencies necessary for the implementation of 
pedagogical activities using a computer, digital gadgets, digital and information and communication technologies: information culture, ICT competence, digital literacy [1-4].

At the same time, the ability to build personal trajectories of professional and personal development based on Internet resources and the resources of the digital educational environment is becoming a leading trend in the education system development. It should be noted that the effective educational process implementation presupposes the coordinated activities of all educational relations participants, teachers, students and parents in the digital educational environment. Material and technical equipment with digital means and teacher's digital competencies as professional skills are not enough.

\section{MATERIALS AND METHODS}

The purpose of the research: to assess the motivational and cognitive readiness of the educational relations participants and the teachers' ability for professional activities in a digital educational environment.

Research hypothesis: the lack of digital means and tools for the formation of a digital educational environment affects the teachers' readiness to implement the educational process in a digital educational environment and prevents the formation of students' digital competencies needed for living in the digital economy. Research objectives: to identify the reasons that caused difficulties for educational relations participants in the educational process implementation using a digital educational environment. Research methods: questionnaires, statistical processing of questionnaires, data comparative analysis, comparing data from several studies [5-7]. A naturalistic design has been chosen to conduct the research, which makes it possible to study the prospect of using the digital educational environment in the educational process under the transition to the digital economy, which determines the non-manipulative and non-controlling nature and proves the validity of the study.

The holistic perspective of the study is due to the organic combination of qualitative and statistical methods and allows us to study the prospects of learning using the digital educational environment as a complex system that includes the motivational and cognitive readiness of all educational relations participants: teachers, students and their parents (legal representatives) and the conditions of professional activities. Attention is paid to the system dynamics in changing the teachers' motivational readiness to work in a digital educational environment, considering the material and technical conditions and value attitudes to activities in the digital educational environment on the part of parents, students and teachers.

The reliability studying the educational relations participants' readiness to implement the educational process using a digital educational environment is proved by the method of comparative analysis of the studies conducted in St. Petersburg and the Russian Federation. We have selected studies conducted between 2019 (i.e. before the forced transition to distance learning during the pandemic) and 2021.

\section{RESULTS}

Based on the study conducted in 2019 by the NAFI Research Centre, the majority of teachers actively use the Internet $(91 \%)$ and do not experience difficulties when working on a computer and using digital devices (89\%). One fifth of teachers $(21 \%)$ have been using digital technology for less than five years. At the same time, teachers are interested in new applications, programs and resources $(77 \%)$ and actively use social networks $(71 \%)$ [8]. The portrait of a schoolteacher, compiled according to the results of the study, is shown in Figure 1 .

According to the study conducted by the Russia Public Opinion Research Center (VCIOM) in 2020, " $21.4 \%$ of teachers (that is, every fifth) do not have sufficient skills to work on the Internet and use network services and resources" [9]. According to the study conducted by experts from the Institute of Education of the Higher School of Economics after the pandemic, $48 \%$ of teachers called the distant learning situation a stressful one [10]. "It can be assumed that the teachers' overly negative attitude towards distance learning is caused by its "unsuccessful version" in spring of 2020" [11]. This statement is confirmed in all studies conducted after the forced transition to a distance learning format in April-June 2020.

100 educational organizations from St. Petersburg took part in the survey "Implementation of main general education programs using distance technologies" conducted by the St. Petersburg Academy of Postgraduate Pedagogical Education in June 2020 [12]. The questionnaire was filled in by the head of an educational organization. The survey participants quantitative composition by types of 
educational organizations was distributed as follows: educational organizations under municipal supervision - 1; gymnasiums - 15; lyceums - 13; general education schools with in-depth subject study - 17; general education schools -54 .

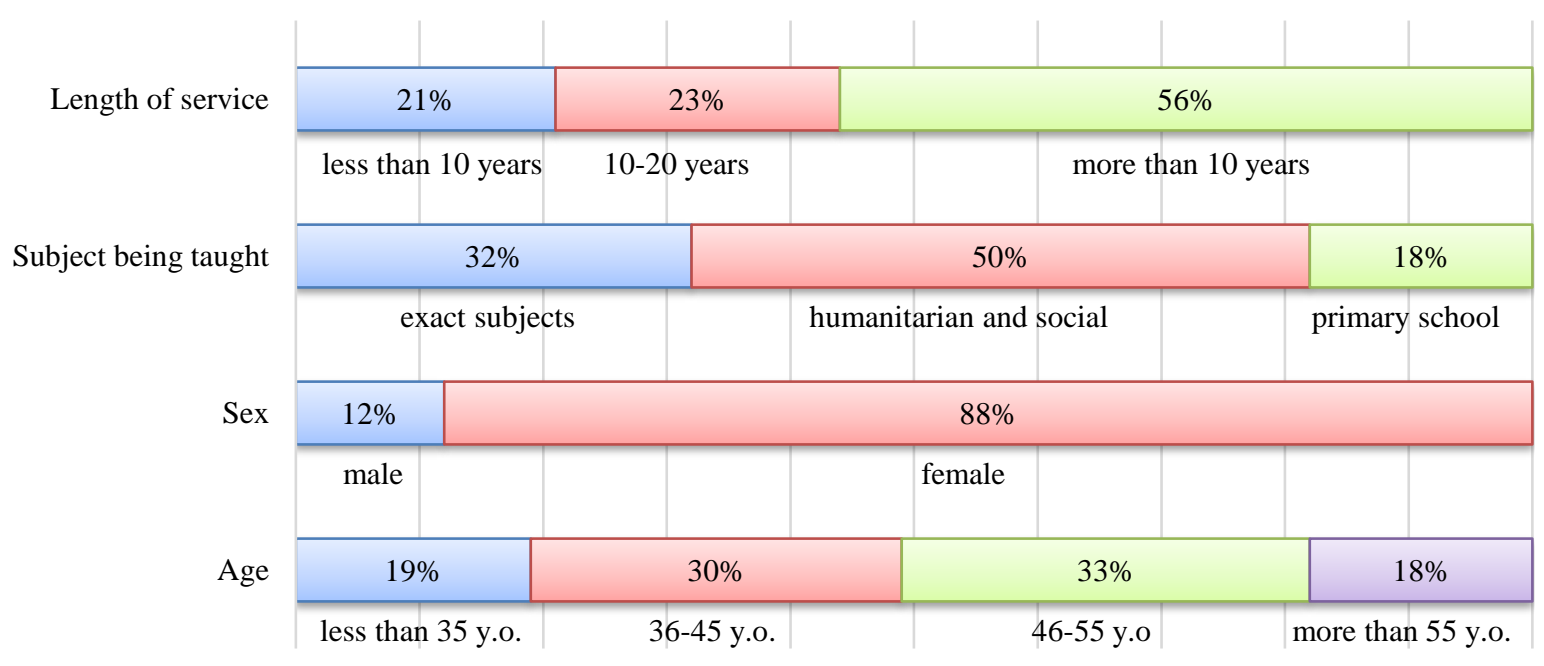

Figure 1. Portrait of a schoolteacher

Source: [8]

The heads note a lack of knowledge and skills among the teaching staff of their educational organizations in the field of information and communication technologies $-31 \%$ and in the field of distance learning didactics $-73.8 \%$. At the same time, $75 \%$ of teachers in these educational organizations completed advanced training courses in the field of information and communication technologies over the past three years, and $38 \%$ of teachers had certificates of completing advanced training courses in the field of online courses development and distance learning organization. This fact demonstrates significant differences between implementing educational process in a fully distance format and the training using a digital educational environment in the full-time educational process.

The assessment of the teacher's readiness has been carried out on the basis of the demonstrated digital literacy skills and abilities, namely, the ability to write a professional personal educational blog (website) on an ongoing basis and the ability to create courses for the "school" distance learning system. $19 \%$ of teachers in educational organizations wrote their own website or blog on an ongoing basis, and $14.8 \%$ of teachers created distance courses for placing in the school distance learning system. This form of pedagogical interaction is used more actively by teachers of gymnasiums and schools with in-depth subject study. The respondents note that technical problems are an obstacle to the distance learning introduction (they are significant for $17 \%$ of teachers), feel uncertainty and fear $-9 \%$ and another $9 \%$ note the lack of experience in working with e-learning platforms.

The study of the degree of parents' readiness to support the child for the successful educational program mastering in the digital educational environment has been carried out by the Family Pedagogy Department of the St. Petersburg Academy of Postgraduate Pedagogical Education in 2019 [13]. According to the results of this study, more than half of the students' parents (56.9\%) believe that the transition to digital education is a natural process, but it does not determine the education quality. Parents note that "the digital educational environment is a new reality in which the child will have to "live and work" $(52.3 \%)$. Let us present the data of the "Implementation of the Main Educational Programs of General Education Using Distance Technologies" survey [12] for comparison: only $20 \%$ of educational organizations have their own distance learning system installed on the school server.

It is believed that the digital educational environment provides new opportunities for the child's self-realization in the educational process, $37 \%$ of the respondents. At the same time, only $14 \%$ of teachers see the personification possibilities when introducing digital technologies into the schoolwork practice [11]. And here the discrepancy between social demand, material and 
technical conditions and the teachers' readiness is noted. This conclusion is indirectly confirmed by the research data on the teacher's readiness to organize the educational process using the digital educational environment presented above.

At the same time, it should be noted that the teachers' readiness to use digital technologies is determined by the availability of existing didactic tools and tools for their development available to the teacher, and the "digital educational environment" formation as a whole. Subjects that were practically not presented on e-learning platforms: Art, Music, WAC, Technology, Physical Education. Therefore, without a practical base, the skills of working with e-learning platforms could not be formed. The lack of digital means "does not make it possible either to facilitate the teacher's routine tasks of checking the task performance or to implement the function of a self-teaching guide. Moreover, most of these resources should be paid for. Most of the teachers have no experience in using them in the educational process" [14]. There is a lack of tools for developing interactive tasks and assessing educational results and the so-called teacher's "automated workplaces".

According to the study conducted by experts from the Institute of Education of the Higher School of Economics during the COVID-19 pandemic, $68 \%$ of parents, $41 \%$, students and $48 \%$ of teachers called the distant learning situation a stressful one [10]. Teachers note the low motivation for learning among a number of students and the fact that "it is difficult to maintain the desired pace of learning without the supervision by" both the teacher and the parents. Some students had low executive discipline and (or) did not have the opportunity to use computer hardware and the Internet, as a result of which they did not complete assignments on time and, thereby, hindered the educational team progress when studying the subject course. Among subject teachers, $41 \%$ are sure that distance learning will always provide worse results compared to fulltime one, this share is slightly less in the group of primary school teachers (39\%) and heads (deputy heads) are even more optimistic - only $28 \%$ of this group respondents shares this point of view.

\section{DISCUSSION}

Based on the above-mentioned research results, the following conclusions can be drawn. Most of the educational process participants have a balanced attitude to the prospect of using the digital educational environment and digital technologies, objectively assess the possibility of their use in the educational process, taking the risks and negative impact into account. At the same time, there is a contradiction between the society and the state demands for learning personalization ("the development of a comprehensively developed personality", "preparation for solving life problems") and a conservative adherence to traditional formats of organizing the educational process.

The results of the studies carried out before and after the forced transition to a distance learning format differ because they characterize the different teachers' value attitudes to the distance education technologies and the demonstrated readiness of the educational process participants to implement training using a digital educational environment.

\section{CONCLUSION}

It is the high-quality digital didactics that largely determines the degree of the teacher's readiness to implement the educational process using the digital educational environment. Digital competencies cannot be formed in the absence of pedagogical interaction in a specially organized digital educational environment. Teachers are motivated to master innovative means and teaching methods, but the lack of digital didactic means prevents the formation of the teacher's digital literacy and professional competencies, corresponding to the life conditions in the information society and the digital economy conditions.

In the future, all participants see the effectiveness of the using digital technologies, and, at the same time, they express the conviction that, as before, the educational process implementation is impossible without a teacher.

\section{AUTHORS' CONTRIBUTIONS}

The authors have contributed to the research and writing the article in the following ratio: Svetlana V. Gaisina - 50\%, Vasily P. Panasyuk - 20\%, Roza M. Sherayzina - 10\%, Marina V. Alexandrova - 10\%, Natalya V. Alexandrova $-10 \%$.

\section{REFERENCES}

[1] L.I. Evseeva, O.D. Shipunova, E.G. Pozdeeva, I.R. Trostinskaya, "Digital Learning as a Factor of Professional Competitive Growth", in Ed. by 
T. Antipova, Á. Rocha, Digital Science 2019, DSIC 2019, Advances in Intelligent Systems and Computing, Springer, Cham. Digital Science, 2019, vol. 1114, pp. 241-251. DOI: 10.1007/978-3-030-37737-3_22

[2] Structure of Teachers' ICT Competence. UNESCO Recommendations [Struktura IKTkompetentnosti uchiteley. Rekomendatsii UNESCO], UNESCO, 2011. (In Russ.). Retrieved from https://iite.unesco.org/pics/publications/ru/files/ 3214694.pdf

[3] A. Martin, D. Madigan, "Digital Literacies for Learning", London: Facet Publishing, 2006, $242 \mathrm{p}$.

[4] D. Issabayeva, L. Rakhimzhanova, U. Abdigapbarova, S. Zhiyenbayeva, "Digital Competence of a Teacher in a Pandemic", in Proceedings of the 9th IC on Information and Education Technology, 2021, pp. 324-328. DOI: 10.1109/ICIET51873.2021.9419644

[5] K. Krippendorff, "Content Analysis an Introduction to Its Methodology", SAGE Publications, Inc., 2018, 472 p.

[6] T.M. Paulus, J.N. Lester, "Doing Qualitative Research in a Digital World", SAGE Publications, Inc., 2021, 376 p.

[7] A.F. Zakirova, "Errors in hypothesis as a methodological reflection subject of a teacherresearcher", Education and Science Journal, 2021, vol. 23(6), pp. 11-42. (In Russ.). DOI: 10.17853/1994-5639-2021-6-11-42

[8] T.A. Aymaletdinov, L.R. Baymuratova, O.A. Zaytseva, G.R. Imayeva, L.V. Spiridonova, "Digital Literacy of Russian Teachers. Readiness to Use Digital Technologies in the Educational Process" [Tsifrovaya gramotnost' rossiyskikh pedagogov. Gotovnost' k ispol'zovaniyu tsifrovykh tekhnologiy $\mathrm{v}$ uchebnom protsesse], NAFI Research Centre, Moscow: NAFI Publishing House, 2019. 84 p. (In Russ.).

[9] S.I. Zair-Bek, T.A. Mertsalova, K.M. Anchikov, "Readiness of Russian Schools and Families to
Learn during Quarantine: An Assessment of Basis Indicators" [Gotovnost' rossiyskikh shkol i semey $\mathrm{k}$ obucheniyu $\mathrm{v}$ usloviyakh karantina: otsenka bazovykh pokazateley], Moscow: NRU HSE, 2020, 32 p. (In Russ.).

[10] Analytical Bulletin of the National Research University Higher School of Economics on the Economic and Social Consequences of the Coronavirus in Russia and in the World [Analiticheskiy byulleten' NIU VSHE ob ekonomicheskikh i sotsial'nykh posledstviyakh koronavirusa v Rossii i v mire], Higher School of Economics, 2020, vol. 6., 158 p. (In Russ.).

[11]E.V. Vanina, M.D. Matyushkina, "Digital Transformation: Key Issues of Teacher Readiness", Bulletin of Naberezhnye Chelny State Pedagogical University, 2021, vol. 2(31), pp. 188-190. (In Russ.).

[12] "Implementation of the Main Educational Programs of General Education Using Distance Technologies" [Realizatsiya osnovnykh obrazovatel'nykh programm obshchego obrazovaniya s primeneniyem distantsionnykh tekhnologiy], Analytical report, St. Petersburg Academy of Postgraduate Pedagogical Education, 2020. 90 p. (In Russ.).

[13]O.V. Erlikh, N.I. Tsygankova, M.G. Kolesnikova, A.V. Zhdanov, "Studying the Degree of Parents' Readiness to Support Their Child for Successful Implementation in a Digital Educational Environment" [Issledovaniye stepeni gotovnosti roditeley $\mathrm{k}$ okazaniyu podderzhki rebenku dlya uspeshnoy realizatsii $\mathrm{v}$ usloviyakh tsifrovoy obrazovatel'noy sredy], Analytical Reference, SPb.: SPb APPE, 2019. 184 p. (In Russ.).

[14]I.A. Karlov, N.M. Kiyasov, V.O. Kovalev, N.A. Kozhevnikov, Ye.D. Patarakin, I.D. Frumin, A.N. Shvindt, D.O. Shonov, "Analysis of Digital Educational Resources and Services for Organizing the Schools Educational Process" [Analiz tsifrovykh obrazovatel'nykh resursov i servisov dlya organizatsii uchebnogo protsessa shkol]. National Research University «Higher School of Economics», Institute of Education, M.: NRU HSE, 2020. (In Russ.). 